\title{
EXPLAINING ADOPTION OF MANAGEMENT INNOVATIONS IN LESS ADVANCED SETTINGS: EVIDENCE FROM TURKEY
}

\author{
Mehmet ERÇEK \\ Management Engineering Department, Faculty of Management, \\ Istanbul Technical University, 34367, Maçka, Istanbul, Turkey \\ E-mail.ercekme@itu.edu.tr
}

Received 26 March 2012; accepted 30 October 2012

\begin{abstract}
This study aims to explain how globally circulating management innovations are adopted by the firms operating in less advanced settings based on an integrative framework. The framework incorporates certain characteristics of national business systems, particular inter-organizational ties developed with transnational or local carriers, and the potential absorptive capacity of the local organizations. By this way, it includes the effects of temporal interactions between different adoption decisions. The components of the framework are operationalized and tested within the Turkish setting by using the adoption data of three different management innovations: TQM, six sigma and lean production. The data is collected from a sample of 375 large-sized firms using a telephone-based interview protocol. While the findings provide satisfactory support for the framework as a whole, they also call attention to the relative differences in the explanatory power of each factor in accounting for the adoption of particular innovations. Variations among the explanatory factors can be attributed to the differences between the life-cycles of TQM, six sigma and lean production as well as to the relative divergence of their conceptual framing.
\end{abstract}

Keywords: adoption, diffusion, management innovation, management fashion, TQM, six sigma, lean production, Turkey.

JEL Classification: O31, M1, C35.

\section{Introduction}

The adoption of Management Innovations (MIs), that is, the implementation of new management models, processes and techniques in an attempt to further organizational goals (Birkinshaw et al. 2008), have received tremendous attention in the recent years (i.e. Abrahamson 1996; Carson et al. 2000; David, Strang 2006; Heusinkveld, Benders 2012; Heusinkveld et al. 2013). Accordingly, studies have documented that the adoption of many MIs, such as Business Process Reengineering (BPR), Total Quality Management (TQM), the Balanced Scorecard (BSC) and Six Sigma (6 $\sigma$ ) have become pervasive (Grint 1997; Haar, Spell 2008; Kennedy, Fiss 2009). While the existing 
literature has significantly enhanced our understanding about how organizational actors adopt, or adapt, particular MIs, I argue that there are still three major limitations about this research stream ${ }^{1}$.

First, almost all of the existing studies have focused on a single MI and, thereby, neglected that there can be interactions between these MIs during the adoption process. In fact, most of these MIs, such as TQM, BSC, $6 \sigma$, and Lean Production (LP), share substantial conceptual content, and their life-cycles considerably overlap (Dahlgaard, Dahlgaard-Park 2006; Modell 2009; Spell 2001). Still, there is no systematic evidence about if a prior decision to adopt an MI may affect subsequent adoption decisions about different MIs.

Second, even though the role of contextual differences in shaping the adoption process has been repeatedly underscored (i.e. Bloom, Van Reenen 2010; Guillén 1994), existing literature has drawn its data extensively from advanced country settings (Kipping et al. 2008). Inattention toward less-advanced settings inhibits extension of theoretical frontiers because of the unique blend of counteracting factors that affect the adoption of MIs in these settings. On the one hand, organizational actors in these settings are under pressure to appropriate MIs unwittingly because of the "societal dominance effects" (Smith, Meiksins 1995). On the other hand, the same actors may be less inclined to accept these innovations at face value due to the institutional voids, family ownership networks and relative resource scarcity prevailing in these settings (Hoskisson et al. 2000). In this manner, exploring how MIs are adopted in less advanced settings further intensify the need for the theoretical integration of rational and social perspectives.

However, literature on the adoption of MIs seems to diverge considerably regarding its theoretical underpinnings and basic assumptions (Ansari et al. 2010; Sturdy 2004). Some scholars try to conceptualize the adoption process as an extension of rational action, and generally explain the adoption of MIs with reference to calculative, benefit seeking behavior (Ansari et al. 2010; Birkinshaw et al. 2008; Sturdy 2004). Mostly driven by the assumption of the rational actor, who seeks to maximize (potential) benefits and avoid from (potential) harms, studies in this perspective often claim that organizations make fairly calculative decisions about the costs and benefits of adopting a MI (Kimberly, Evanisko 1981). Others draw on psycho-social and cultural factors, many of which ascribe little importance to rational accounts in comparison to legitimacy gains (Sturdy 2004). Scholars, in this strand, conceptualize adoption as a social process and depict organizational actors as rather passive consumers of MIs, many of which are categorized as "fashionable" and "faddish" (Abrahamson 1996). These conflicting theoretical claims confine integrative research efforts and restrict potential explanations, which may be the two different sides of the same coin.

Accordingly, this study aims to explain the adoption patterns of three conceptually related MIs, namely the TQM, $6 \sigma$, and LP, within one of the emerging economies under

\footnotetext{
${ }^{1}$ Adoption is defined as a decision to implement a particular MI within the boundaries of a particular organization or organizational unit irrespective of the extent of transformation it goes under throughout the process of implementation.
} 
scrutiny nowadays, namely, the Turkish setting ${ }^{2}$. In order to explain how contacts between global disseminators of MIs and local organizational actors be engendered and regulated under the constraints of a less advanced setting, an integrative theoretical framework has been developed. Within this framework, I combine pertinent measures of Turkish national business system, organizational ties built with transnational and local carriers, and effects of learning and entrenchment to elucidate the local adoption patterns. The effects of these factors are tested on a data set, gathered through a semistructured interview from a sample of 375 large-scale private business organizations operating in Turkey ${ }^{3}$. Although there exists previous empirical work in this domain about Turkey, these studies have either confined themselves to a single theoretical camp (Özen 2002; Özen, Berkman 2007), or disregarded any temporal association between multiple MIs (İşeri-Say et al. 2008). Furthermore, the choice of $6 \sigma$ and LP as the conceptual and temporal successors of TQM (Dahlgaard, Dahlgaard-Park 2006) provides a unique opportunity to observe if these MIs compete with, or complement each other within a pre-defined contextual and temporal cosmos.

The study is organized under five sections to convey its arguments. The next section elaborates how supposedly different theoretical perspectives of comparative business systems (CBS), management fashion theory (MFT) and organizational learning theory (OLT) can be combined to account for the adoption of MIs within a less-advanced country setting. The second section introduces the protocols for determining the population and sample, measures of the study, as well as the basic characteristics of the sample firms. The third section reveals the findings gathered from statistical analyses. Finally, the study concludes by discussing the contributions made to the extant literature together with the limitations and further research implications.

\section{Combining rational and social accounts: national business systems, carriers, and organizational learning}

Due to a growing sensitivity for national institutional differences, several scholars have underscored that the legitimacy concerns of organizational actors have to be re-considered for countries, which do not participate in the production phase of the MIs (Djelic, Quack 2003). Since institutionalization is conceptualized as a staged social construction process, starting with habitualization, followed by objectification, and concluding in sedimentation (Tolbert, Zucker 1996), organizational actors in less advanced countries never experience the first stage, where micro level theorization efforts eventually evolve into shared

\footnotetext{
${ }^{2}$ For those who are less familiar with these MIs, TQM is an integrative MI, built on the premise of continuously improving the quality of products and processes to ensure customer satisfaction (Juran, Godfrey 1998). $6 \sigma$ also seeks to improve the quality, but its focus is on minimizing the defects and process variability by data driven tools on a project by project basis (Senapati 2004). LP, on the other hand, refers to a system of production, which tries to eliminate any wasteful effort that does not create value for the end consumer (Shah, Ward 2007). The conceptual relations between these MIs will be further evaluated in section 1.4.

${ }^{3}$ The interviews are conducted over the phone subject to a protocol that is explained in section 2 .
} 
meaning sets and collective activity patterns. Instead, these actors take MIs for granted, based on the assumption that MIs have already been legitimized in "high-status institutional contexts" (Sanders, Tuschke 2007), or "societal role models" (Smith, Meiksins 1995), where these MIs initially emanated. This leads to externally induced legitimation, which nullifies local re-theorization, or critical evaluation of the inflowing MIs with respect to their performance allegations. Local concerns for legitimacy are less likely to be influenced by field level institutional factors since less advanced settings usually lack comparable institutions at the field level, such as autonomous regulatory bodies, accreditators, professional organizations etc., which can strongly shape these fields and construct dominant frames of mind among the constituents of these fields (Khanna, Palepu 1999). In rare cases, where such field level institutions exist, it is most probable that they fail to perform effectively and/or their frameworks are also borrowed from high-status institutional contexts (Djelic, Quack 2003). Consequently, it becomes highly likely that the inflowing MIs are devoid of local scrutiny with respect to their performance aspects and are already perceived as legitimate. Under these conditions, I argue that the local adoption relies heavily on how "contacts" between transnational disseminators of MIs and local organizational actors are made possible and a set of key factors, which enable and regulate such contacts. Integrating CBS approach, MFT and OLT, I subsequently develop a new framework and identify three sets of interrelated factors, which are critical in enablement and regulation of such contacts. In the following sections, I will elaborate on each of these factors separately and formulate a set of testable relationships for the Turkish setting.

\subsection{National business systems}

First, building on the arguments of CBS approach, I propose that the business system configuration of the national setting strongly conditions how and to whom externally sourced MIs will initially be channeled. National business systems (NBSs) refer to the "distinctive patterns of economic organization that vary in their degree and mode of authoritative coordination of economic activities, and in the organization of, and interconnectedness between, owners, managers, experts, and other employees" (Whitley 1999: 33). This definition suggests that by analyzing the characteristics of an NBS, one can identify not only the dominant economic actors, who have significant authority over the coordination of economic activities within a national setting, but also determine the basic mechanisms employed by these actors to make such coordination possible. In this sense, dominant economic actors represent one of the most important factors that determine the adoption of MIs in a national setting, because they are endowed with superior material and social capital. Building on their authority these actors can either directly engage in, or indirectly faciliate and regulate contacts between key transnational disseminators and local actors.

In his work, Whitley (1999) has identified six divergent NBSs, namely, fragmented, coordinated industrial district, compartmentalized, state organized, collaborative and highly coordinated ones ${ }^{4}$. Several scholars have associated Turkish NBS with the "state organized"

\footnotetext{
${ }^{4}$ One can refer to the works of Whitley and his colleagues for the basic characteristics of these NBSs (i.e. Whitley 1999, 2000; Whitley, Kristensen 1996) for a fuller perspective of NBS.
} 
type (Gökşen, Üsdiken 2001; Özen 2002). One of the most striking characteristics of this NBS is that coordination of economic activities are rather authoritative, in other words, how economic activities shall be organized is centrally decided by the state and by a small number of owner elites, who control a significant portion of economic activities by "business group" structures (Whitley 1999). Less coordination exists between other elements of the NBS, namely, the worker unions, workers, managers and experts. In this respect, a more careful analysis of the state policies and ownership based controls becomes necessary to account for how these two dominant actors influence the adoption of MIs.

Da Silveira (2001) suggests that the speed, pattern and mechanisms of innovation diffusion in less advanced countries are strongly contingent on government policy about the control and coordination of economic activities. Among many possible policy alternatives, Hoskisson and his colleagues (2000) specifically mentioned ones that are related to the relaxation of state controls and ownership in the local economy as well as the liberalization of trade and investment flows. Once governments initiate structural change programs toward opening up local economies to global competition and establish legal frameworks to uphold mechanisms of market exchange, organizational actors in such contexts will be more likely to consider adopting MIs in order to better respond to the intensifying competitive pressures.

In the Turkish case, several scholars revealed that the state's reactive response for the establishment of a market-based economy had begun at the beginning of 1980s and intensified all through 1990s (Kepenek, Yentürk 2001; Öniş, Şenses 2007). One of the most important events that marked the liberalization of markets and intensification of the local competitive landscape in Turkey was the signature of Customs Union Agreement with the European Union in 1995. This was especially important because it came immediately after a national economic shock and ensuing structural change initiatives launched by the government in 1994 (i.e. large-scale privatization program, increased autonomy of central bank and rehabilitation of social security system). While these efforts for liberalization had rather limited impact, and another national politico-economic shock occurred in 2001, the latter stimulated the implementation of a more substantial structural change program starting from 2002, within which constitution of autonomous regulatory institutions, liberalization of exchange rates, reforms for banking industry, and an aggressive privatization agenda was included (Keyman, Öniş 2007).

Özen (2002) argues that the diffusion of TQM in Turkey has accelerated in 1990s because of the neo-liberal policies followed by the governments. According to him, local propagators of TQM were able to legitimize the adoption of TQM "because of the changing economic and political conditions" during 1990s (Özen 2002: 65). Thus, it becomes reasonable to assume that the aforementioned historical events in Turkey can be influential in predicting the chronological adoption of particular MIs. Taking the lifespans of MIs into account (see Fig. 1), on which this study have focused, it is possible to assume the following relationships.

H1a: Due to the first wave of liberalization efforts of the state, relatively more firms have adopted TQM in Turkey after 1995 than before. 
H1b: Due to the second wave of liberalization efforts of the state, relatively more firms have adopted $6 \sigma$ and LP in Turkey after 2002 than before.

\subsection{Effects of business groups}

The significance of business groups 5 in Turkey and their close connections with the state agents and politicians have been previously explored (Buğra 1994). Regarding the findings from research, Turkish business groups, or, in their native conceptualization, Turkish Family Holdings, represent federations of unrelated businesses tied by tight ownership controls (Gökşen, Üsdiken 2001). These structures permeate different industries and leverage contactual relations between multinationals and local agents (Erçek, Günçavd1 2010). Therefore, vertical ownership ties, which allow holding headquarters to influence affiliates' conduct, combined with social and economic ties that are created between vertically integrated affiliates, can help leveraging of inter-affiliate knowledge spillovers (Yiu et al. 2007). Scholars have shown how structural and role equivalent network positions help dissemination of various management practices (Westphal et al. 1997). Others presented preliminary evidence, which indicated that Korean business groups actively sought and adapted Western MIs in late 1990s (Wright, Kwon 2006). Thus, it is possible to assume that Turkish business groups may also facilitate the adoption of MIs among their affiliates, based on strong ownership controls exercised either by tight board interlocks, or over vertical hierarchical authority chains.

H2: Members of core Turkish business groups will be more likely to adopt TQM, $6 \sigma$ and LP.

\subsection{Management fashions and carriers of MIs}

While the configuration of a NBS affects how MIs are initially channeled to the dominant local actors, MFT helps to identify particular transnational and local actors, which deliberately engage in disseminating management ideas and thereby, enable realization of contacts between the former and the latter. In his seminal article, Abrahamson (1996) distinguishes members of a "fashion-setting-community", who purposefully supply popular management ideas to managers. Others expand Abrahamson's proposal to the global landscape and suggest that there are particular social actors, who engage in worldwide expansion and circulation of a wide collection of management knowledge - including fashionable management ideas (Sahlin-Andersson, Engwall 2002). In this regard, the concept of "carrier" has been coined to denote a set of interlinked social actors, who engage in codifying, transforming and circulating management ideas (Kipping et al. 2008). Studies carried out in the domain of MFT have provided substantial evidence about the roles and activities of particular carriers such as multinational corporations (Arias, Guillén 1998), management gurus (Clark, Greatbatch 2002), professional associations (Erçek, İşeri-Say 2008) and consultants (Sahlin-Andersson, Engwall 2002).

\footnotetext{
${ }^{5}$ A business group refers to the gathering of formally independent firms under the influence of multifaceted links, including (cross) ownership, internal markets and/or social relations - family, kinship or personal friendship (Yiu et al. 2007).
} 
Yet, much of the activities described in these studies are not directly transferable to less advanced country settings. For example, management gurus often stem from advanced country contexts and most of their performances take place in these contexts. Likewise, Erçek (2008) reveals that the consultants' role in disseminating $6 \sigma$ among prominent Turkish firms is confined mostly to the technical training aspects, which take place following the adoption decision.

On the other hand, Sayım (2011) underscores that the multinational corporations have channeled different management practices from their headquarters to their Turkish affiliates. A multi-country study about the diffusion of ISO 14001 has found that the presence of multinational corporations in a country in the form of foreign direct investment (FDI) increases the likelihood of the adoption of ISO 14001 by domestic firms (Perkins, Neumayer 2010). Increased liberalization practices in Turkey, especially privatizations, attracted more FDI in the last decade (ISPAT 2011). Considering that direct ownership controls are important in the Turkish NBS, ownership ties created with multinational corporations may help transfering of MIs to the local setting.

H3: Firms with foreign capital ownership ties will be more likely to adopt TQM, $6 \sigma$, and LP.

Apart from aforementioned carriers, several scholars have emphasized the significance of the efforts of Turkish Quality Association (Kalder) in the initial adoption and subsequent diffusion of TQM in Turkey (Erçek, İşeri-Say 2008; Özen 2002). Kalder represents a rather unique professional network, which can alleviate its lack of legitimacy by establishing network ties with the dominant economic actors-state and business groupsof the Turkish NBS. Established in 1991, Kalder's membership list exceeds 1000 Turkish public and private organizations. Another local professional association is the Lean Institute Turkey (LIT), which was established in 2002 as a partner of the global network of Lean Enterprise Institute, founded by James P. Womack. Even though LIT is much smaller and less established compared to Kalder, it has substantially expanded its activities over the past five years. On its website LIT broadcasts 108 Turkish companies, which have partnered with the institution on different terms. Unfortunately, no such organization exists in Turkey to disseminate $6 \sigma$, which can assume the role of a local carrier. Hence, I argue for the following aphorism.

H4: Firms, which have developed membership ties with Kalder, are more likely to adopt TQM, whereas firms, which have developed ties with LIT are more likely to adopt LP.

\subsection{Organizational learning theory and interaction of MIs}

NBSs and carrier activities represent structural relations, which enable and/or constrain the most probable instances of contacts occurring between external and local agents in order to facilitate the adoption of a MI. In other words, such structural relations increase the chances of local agents' exposure to externally circulating MIs (Zahra, George 2002). Following these arguments, however, I assert that the local organizational actors are not passive and mindless consumers, and however constrained, they retain considerable evaluative 
capacity regarding the adoption and/or adaptation of MIs. Thus, unlike the conventional predictions of MFT, I argue that the adoption of MIs further depends on the capacity of local organizational actors to value and acquire external knowledge. Accordingly, I build on the OLT literature to explain the possible sources of such organizational capacity, which enables a local organization to explore and acquire an externally circulating MI.

Within the OLT, the exploration and acquisition of external knowledge represent two critical phases of the absorptive capacity construct (Cohen, Levinthal 1990). These two phases are acknowledged as potential absorptive capacity, which refers to the acquisition and assimilation of external knowledge, irrespective of the degree and success of its integration into operational processes (Lane, Lubatkin 1998; Zahra, George 2002). Building on previous arguments, which suggest that MIs are externally legitimized in less advanced settings and thus, the value of MIs are taken for granted for local organizational actors, I posit that the determinants of potential absorptive capacity can mainly be a function of three factors: i) the presence and effectiveness of inter-organizational ties, such as partnerships and alliances (Todorova, Durisin 2007), ii) knowledge complementarity (Lichtenthaler 2009) and iii) past experience, to the extent that, the latter is deposited in organizational memory (Zahra, George 2002). Considering that my previous discussions have predominantly covered potential inter-organizational ties that can channel externally sourced MIs under a less-advanced country context, I will henceforth concentrate my attention to the remaining two factors.

Knowledge complementarity relates to the existing knowledge bases of a firm and its degree of overlap with regard to the external knowledge (Zahra, George 2002). Scholars of OLT have repeatedly underscored that the potential absorptive capacity is positively affected by the degree of overlap between firm's existing knowledge bases and the external knowledge components (Lane, Lubatkin 1998; Lichtenthaler 2009). Thus, the discussion of knowledge complementarity requires comparative evaluation of this study's focal MIs with respect to their degree of conceptual overlap or divergence.

Based on their respective definitions, there are works, which see TQM, $6 \sigma$ and LP as theoretically overlapping MIs (Senapati 1994; Dahlgaard, Dahlgaard-Park 2006). All of these MIs share similar problem solving and data analysis tools, all are geared toward customer satisfaction, all seek to minimize variation in processes and products, all emphasize collaborative approach and cultural transformation (Juran, Godfrey 1998; Pepper, Spedding 2009; Senapati 2004; Womack, Jones 1996). Minor differences refer to the degree to which the latter factors are highlighted vis-à-vis in the deployment process and the extent to which bottom-line measures are linked with deployment success (Antony 2007). In this sense, both LP and $6 \sigma$, accentuate data driven improvement methodologies more intensely and they incorporate a keener focus on the measures and measuring techniques- of resource utilization (Antony 2007; Womack, Jones 1996; Shah, Ward 2007). Based on these discussions, I argue that there is significant conceptual similarity between these MIs, and that $6 \sigma$ and LP complements TQM especially in the measurement and resource utilization aspects.

A study reports that the adoption of ISO 14001 certification by a firm is related to the firm's previous adoption of ISO 9001 certification, because there are substantial learning 


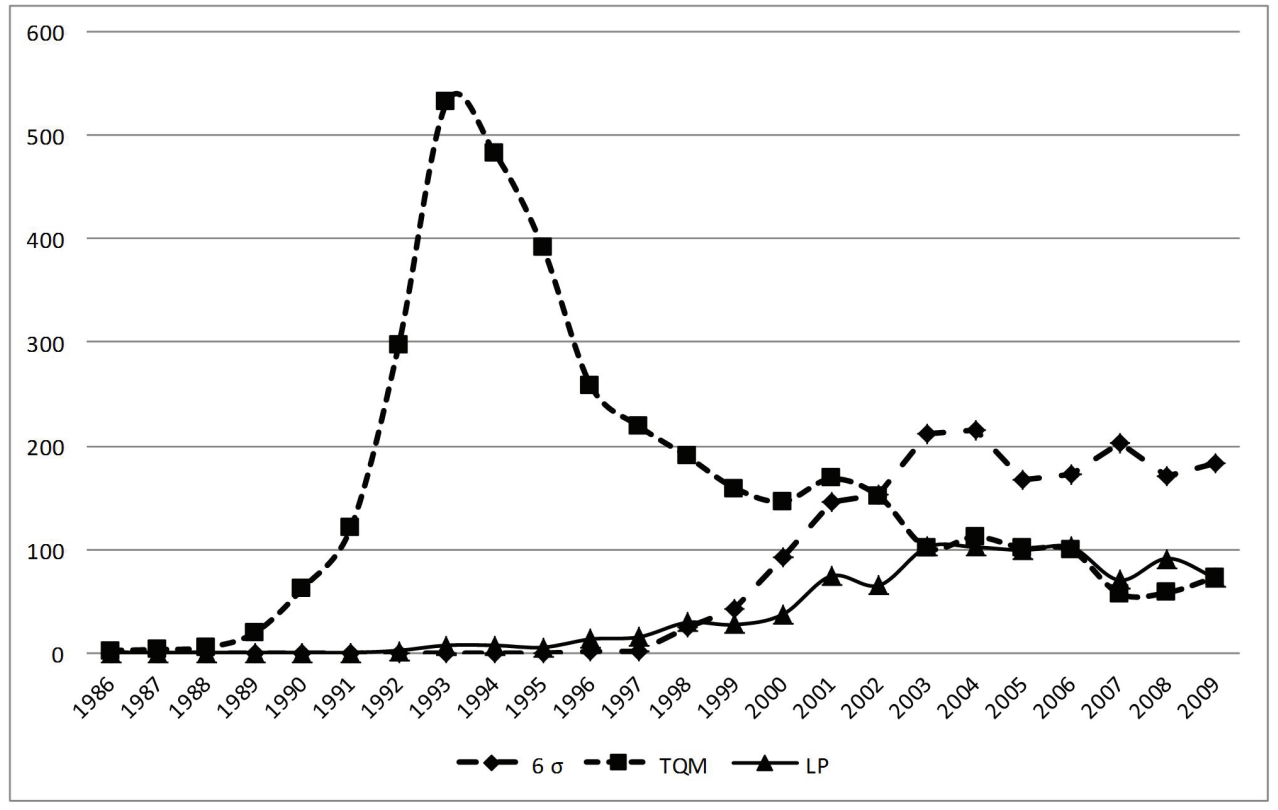

Fig. 1. Annual number of texts (adjusted) entitled $6 \sigma$, TQM and LP in the ABI-Inform database, 1986-2009

advantages (Corbett, Kirsch 2001). Since TQM, $6 \sigma$ and LP are also complementary, it can be argued that organizational actors, which adopt one or more of these MIs, will be more likely to adopt the remaining MIs. This time the question becomes which MI is most likely to be initially adopted and if organizational actors will abandon their existing innovations in favor of a new one.

In order to determine the sequence of adoption patterns, a systematic analysis of the temporal prevalence of TQM, $6 \sigma$ and LP is required. Figure 1 is prepared from the Proquest (ABI-Inform) database to illustrate the temporal patterning of each MI based on their bibliometric popularity measures ${ }^{6}$. The graph clearly indicates that the emergence of TQM is prior to other MIs. Based on the chronological sequence of adoption patterns and previous discussions, the following relationship can be posited.

H5: Turkish companies, which have previously adopted TQM, will be more likely to adopt $6 \sigma$ and LP as well.

Proponents of MFT and OLT assert conflicting claims when it comes to theorize if firms abondon existing MIs to accomodate a new one, or choose to cohabit multiple MIs. Abrahamson and Fairchild (1999) claim that organizational actors "superstitiously" learn to adopt and use MIs, without actually theorizing and transforming their mental

\footnotetext{
${ }^{6}$ Titles of articles are extracted from the database by filtering the key words of "total quality", "six sigma", "lean production", "lean thinking" and "lean management" for each year. The number of hits per year are adjusted according to the variance in the overall number of articles in the database.
} 
schemata, while others argue that in cognitive or experimental models of learning, it is possible to observe changes in the mental models of organizational actors (Gavetti, Levinthal 2000). Superstitious learning assumes that acquired activities do not translate into organizational memory, do not tightly entrench themselves into formal roles and routines, and thereby, fail to be reproduced, and are easily replaced (Zeitz et al. 1999). However, if an organization thoroughly explores and exploits an MI, substantial amounts of organizational learning may take place at multiple levels (Crossan et al. 1999). In this way, some of the adopted MIs may become tightly entrenched in organizational routines, so that it becomes unlikely to abandon them without considerable costs (Zeitz et al. 1999; Perkmann, Spicer 2008). Once an MI is entrenched in routines and becomes a part of organizational memory, it can be systematically reconfigured to invoke new exploration, interpretation and integration activities (Lichtenthaler 2009).

I argue that entrenched MIs may invoke prospective exploration for relevant external knowledge and may result in the adoption of conceptually related MIs. This argument suggests that positively perceived past experience with a MI will stimulate prospective acquisition and assimilation of new and complementary external knowledge (Zahra, George 2002). Indeed, there are case based examples in the literature about how organizational actors blend TQM with the BSC (Modell 2009) and 6 $\sigma$ (Erçek 2008). In these cases, there is sufficient detail about how organizational actors re-combine existing components with new components based on their perceived relatedness. Erçek (2008) also suggests that organizations not only create hybrid innovations by blending old and new components, but maintain some of the existing routines, either for political or legitimacy purposes. Therefore, organizational actors may choose multiple MIs to cohabit as well, even if it is not efficient from a rational perspective, but makes sense in terms of social gains.

H6: Turkish firms, which have entrenched TQM into their organizational structures as formal roles and routines, are more likely to adopt and retain LP and $6 \sigma$ in their organizations rather than abandoning one or more of these innovations.

Finally, noting that absorptive capacity is based on the existence of "formal processes" for acquisition, assimilation, transformation and exploitation (Todorova, Durisin 2007), organizations of less advanced countries need to be assessed for the existence of such organizational capabilities. I argue that these formal processes incur substantial costs, which necessitate significant material capacity for an organizational actor to afford. Larger organizations generally have more resources and tend to have a more complex structure (Haar, Spell 2008). Therefore, the potential to seek treatments for structural incompatibilites are higher and the cost of adopting MIs are bearable for larger organizations (Damanpour 1992). Correspondingly, İşeri Say and her colleagues (2008) reported that larger Turkish organizations had adopted more MIs compared to smaller ones. Taking these arguments into consideration, I argue for the following relationship.

H7: Large-sized Turkish business organizations are more likely to adopt TQM, $6 \sigma$ and LP. Having discussed the hypothesized relationships, the next section lays out the details of the sampling, data and measures employed in this study. 


\section{Sampling, data and measures}

In order to determine the population of big business organizations in Turkey, which constitute the dominant economic actors, I have combined mainly three listings. The most established business listing is provided by Istanbul Chamber of Industry (ICI), which covers top 500 private and public manufacturing enterprises in Turkey. ICI's "2009 Top Manufacturing Enterprise List" was employed in this study as the main list to determine the big business population after removing public enterprises. Since the hypothesized relationships incorporate possible effects of foreign ownership, members of International Investors Association of Turkey (YASED) were also included in the population. The members of YASED were also added to the former list, after eliminating overlapping and smaller ones (employee number $<250$ ). Consequently, the lists of biggest firms operating in the aviation, telecommunication and retail banking industries are included in the population in an attempt to better represent the service industry. The overall number of the population, to which the data collection procedure was applied, amounted to 728 .

After determining the big business population, a telephone based, semi-structured interview protocol was designed and conducted. In order to increase reliability, at least two functional departments were questioned about the adoption decisions of the firms. Initially, the human resources, or corporate communications departments were contacted and questioned, then a request was made to transfer the call to other relevant departments, such as quality assurance or management, lean operations, strategic planning, corporate relations etc. Also, each respondent was asked about the responsible departments/roles for each respective MI in the organization to check for reliability. In cases of apperant contradictions between department data, the case was terminated. All the data were simultaneously entered in a pre-prepared spreadsheet during the call. A retrospective reliability check was performed by comparing archival records of companies in the sample, which contained historical evidence indicating adoption of respective MIs. Out of 23 cases, there was only one year discrepancy associated with a single TQM adoption case (the archival record indicated 1 year early adoption). Hence, I believe that the data represent accurate retrospective accounts of the objectified occasions - organizational adoption decisions.

The participating companies were questioned about the adoption and abandonment dates for each MI, namely TQM, $6 \sigma$ and LP. They were also questioned about if they had adopted European Foundation for Quality Management's Business Excellence Model and other assurance standards and methodologies, such as ISO 9001, 14001, 22000 and 16949 certifications. All the demographic data such as the industrial classification codes, employee numbers and plant locations were also coded. After eight months of interviewing, the process was terminated in April 2010 with 375 usable firm interviews (51.5\% response rate).

The list of organizations with local business group membership is determined by eliminating the enterprises with public and foreign capital ownership from the list provided by Çolpan and Hikino (2008). The elimination procedure yielded 29 business groups. These business groups controlled 65 affiliated companies in the sample. Table 1 summarizes the basic characteristics of the sample firms. 


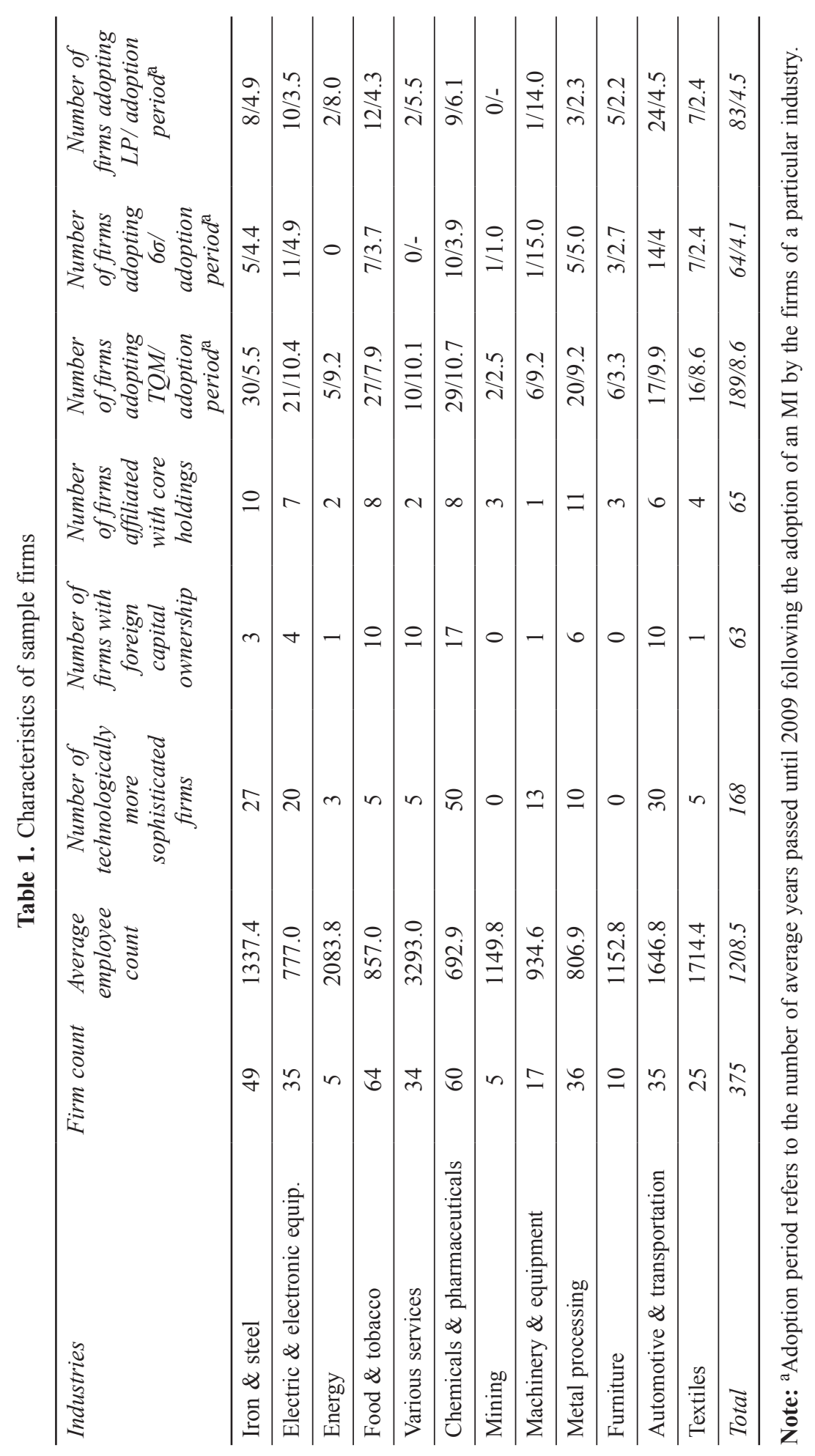


The dependent variable for the analysis, which refers to the organizational adoption and/ or abandonment decision made by firms for TQM, $6 \sigma$ and/or LP, is coded in relevant categories ( 0 = non-adoption; 1 = adoption; 2 = abandonment). In addition to these, the year of the adoption and/or abandonment decision made by a firm is also coded to discern the temporal diffusion pattern, which is depicted in Figure 2.

Affiliation with largest Turkish private holdings is coded as a binary variable. The measure for foreign ownership ties is also binary coded for firms with more than $10 \%$ of their capital owned by non-native entities. Organizational size is coded in terms of employee numbers at the time of the interview.

A quality entrenchment metric is developed to test H6, with regard to a summation score of four different categories. If an organization reports: i) adoption of TQM for more than 5 years, ii) has established a formal (managerial level) department containing "quality" or "integrated systems" words in its title, iii) holds at least one formal quality assurance certification, and iv) reports adoption of European Foundation of Quality Management business excellence model, its score adds up to a total of four. Thus, the entrenchment metric ranges from 0 to 4 , indicating no entrenchment of quality practices for the former and strong entrenchment of quality practices for the latter.

Apart from these measures I include technological sophistication as a control variable, since it has been previously found to determine the adoption of TQM (Westphal et al. 1997). While OECD provides technological sophistication measures for different industries, those measures are primarily based on R\&D intensity, which fail to represent relative technological sophistication within less-advanced settings. Alternatively, I chose to construct a more indigenous measure to determine technological sophistication, whereby two experts independently coded four-digit classification codes of sample companies into two categories of technologically sophisticated and technologically unsophisticated. They used three criteria, namely: i) relative complexity of firm processes, ii) relative complexity of firm outputs, and iii) relative intensiveness of capital, to encode the scale. The match between coders approximated $81 \%$, indicating a high reliability. Remaining mismatches were coded by unanimity following a round of negotiations.

\section{Findings}

The general adoption patterns of TQM, $6 \sigma$ and LP in Turkey seems to be in line with expectations (see Fig. 2). The adoption of TQM by Turkish companies has preceded both $6 \sigma$ and LP, indicating a pattern, which is similar to the one observed in international discursive dissemination (Fig. 1), albeit with a relatively smaller time lag. Yet, the sharp decline of TQM observed in the bibliometric data seems not to be the case in Turkey. Many large sized firms have continued to adopt TQM until very recently. Besides, interest in other MIs seems to be in full swing, and it is early to judge if they have yet enjoyed the peak of attention by Turkish firms. The patterns are also in line with the H2. There are substantially more number of companies (156 out of 189 , or $87.8 \%$ ), which have adopted TQM after 1995, following 1994 national economic shock, and the subsequent efforts for liberalization. Likewise, the majority of companies, which have 
adopted $6 \sigma$ and LP, do so after 2002, when another wave of stabilization and liberalization ensued ( 60 out of 64 , and 72 out of 83 for $6 \sigma$ and LP respectively).

A simple binomial test, comparing if the proportions of companies adopting TQM are equal or unequal between the two periods (1990-1995 and 1996-2009), is found highly significant $(\mathrm{p}=0.00)$. Similarly, the tests comparing the proportions of companies adopting $6 \sigma$ and LP, between 1992-2002 and 2003-2009 periods, are found highly significant as well $(\mathrm{p}=0,00)$. Even though, the data set did not permit more robust estimations for the effects of time, when the results of these tests and the adoption patterns illustrated in Figure 2 are combined, they provide support for the relationships expressed in $\mathrm{H} 1 \mathrm{a}$ and $\mathrm{H} 1 \mathrm{~b}$.

A striking finding, which is at odds with the reported adoption patterns in the management fashion literature, is about the pattern of abondonment. As it has been discussed, proponents of MFT assumed that the patterns of adoption and abondonment should be similar with a certain time lag, since organizations would accommodate a single MIin-use due to insufficient resources (Abrahamson, Fairchild 1999). However, findings indicate that Turkish companies do not seem to abondon MIs, even when they decide to adopt a new one. A total of only 5 abandonments were reported, 4 of which were about TQM and the other was for LP. While two companies reported that an external triggering event (2001 economic shock) were among the primary causes of abandonment of the TQM program, the other two mentioned various internal causes (lack of top management support, frequent change of strategic initiatives etc.). The firm, which abandoned LP, declined to mention any causes.

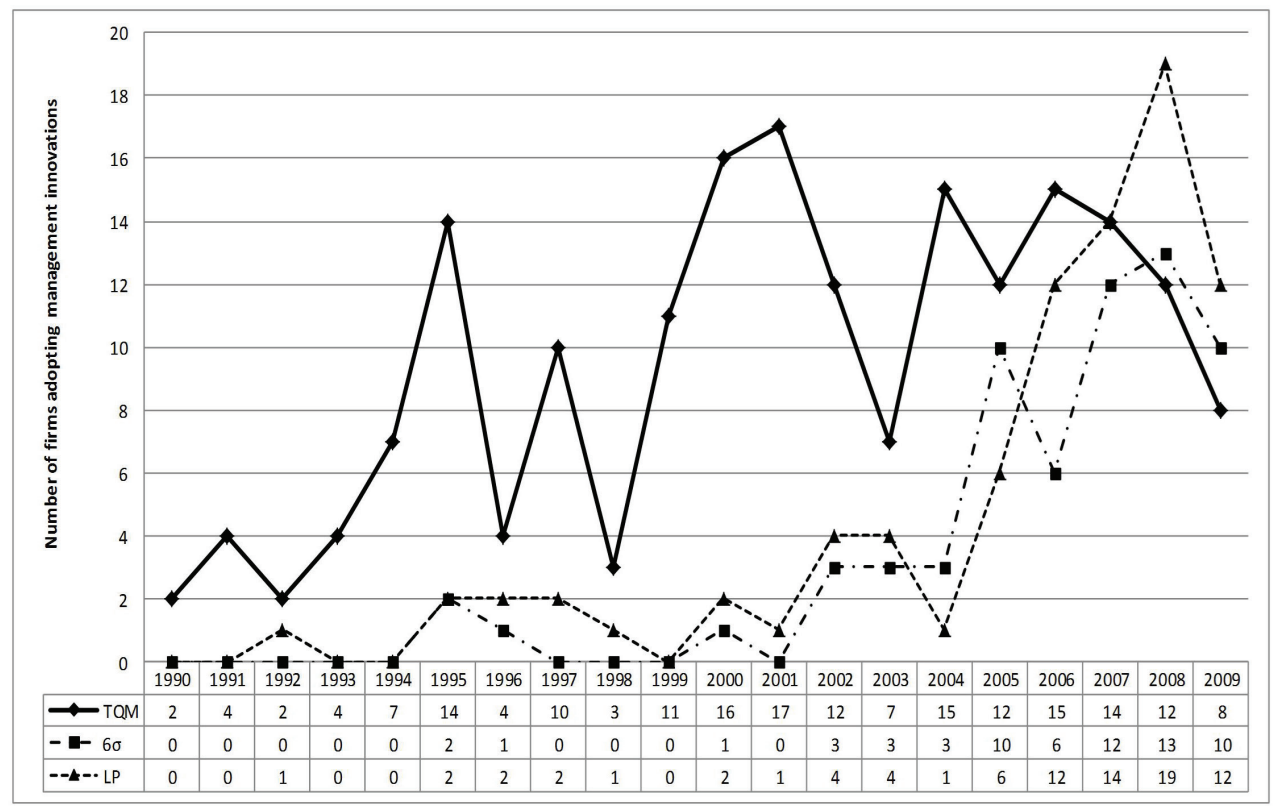

Fig. 2. Number of firms adopting TQM, 6 $\sigma$ and LP in Turkey, 1990-2009 
In general, 223 companies, or $59.5 \%$ of all sample, have declared that they had used at least one of the investigated MIs. Out of these 223 companies, 33 of them reported adoption of all three, 55 of them adoption of two, and 135 of them reported adoption of a single MI. With a small number of exceptions (11 out of 88), Turkish companies prefer to combine TQM with other MIs, which provides support for the fifth hypothesis. In none of the cases, where TQM was combined with another MI, the adoption dates of $6 \sigma$ or LP preceded the adoption date of TQM. Therefore, the sequence of the adoption decisions do not violate the underlying logic of the relationships posited in H5.

To test the hypothesized relationships in $\mathrm{H} 2, \mathrm{H} 3, \mathrm{H} 4, \mathrm{H} 5$ and H7, a Multivariate Probit Regression Model (MPRM) was employed, within which adoption decisions of TQM, $6 \sigma$ and LP were used as binary-coded dependent variables ${ }^{7}$. Since abandonment decisions were observed in only 5 cases, those cases were not included in the analysis. Thus, the dependent variables of the models have ultimately become the decisions made by remaining 370 firms for adopting TQM, $6 \sigma$ and LP, or not $(1=$ adopt, $0=$ do not adopt). MPRM was preferred because the equations for estimating the probabilities of $6 \sigma$ and LP adoption decisions required inclusion of a possible previous adoption decision made by the same firm on TQM as an estimator. Besides, the same firms in the sample adopted multiple MIs in a considerable number of cases. MPRMs are better suited to overcome endogeneity problems caused by such decisions, because they let errors of each equation to correlate simultaeously. As it has been eloquently explained by Cappellari and Jenkins (2003), MPRMs can be expressed as multiple forms of seemingly unrelated probit regression models. The solutions of these models are based on joint normal distribution functions, which can ultimately be calculated by simulation algorithms. For such models, the correlations between the error terms of each simultaneous equation are reported by the $\rho$ coefficients. The results of the MPRM is illustrated in Table 2 .

First, the results obtained from the likelihood tests of $\rho$ coefficients have corroborated the choice of MPRM use. Since the tests indicated that $\rho$ coefficients are significant, it can be argued that MPRM is a better choice over single, or bivariate probit models. Second, coefficients of estimators suggested that the main factors of the integrative model were found statistically significant in at least one of the three equations. Put differently, the integrative theoretical framework built in the preceding sections, which combines divergent traditions of research to explain adoption of MIs, has found considerable empirical support. While the effects of factors that are combined under the integral model, namely the national institutional configuration, ties with carriers, and potential absoptive capacity, have been found significant in explaining different adoption decisions, the relative importance of each factor seems to vary considerably in their explanatory power.

To be more precise, model estimations provided strong support only for $\mathrm{H} 4$ and H5, whereas the remaining hypotheses received only partial support. In other words, firms operating in Turkey are definitely more likely to adopt $6 \sigma$ and LP if they have previously adopted TQM. Besides, ties developed with local carriers significantly predicted

\footnotetext{
${ }^{7}$ I am grateful to the anonymous reviewers for their suggestion of the use of MPRM.
} 
Table 2. Multivariate probit regression model estimates of TQM, $6 \sigma$ and LP adoption by Turkish firms

\begin{tabular}{|c|c|c|c|}
\hline \multirow[b]{2}{*}{ Estimators } & \multicolumn{3}{|c|}{ Regression equations } \\
\hline & $\begin{array}{l}\text { TQM adoption } \\
\text { Equation }_{1}\end{array}$ & $\begin{array}{c}6 \sigma \text { adoption } \\
\text { Equation }_{2}\end{array}$ & $\begin{array}{c}\text { LP adoption } \\
\text { Equation }_{3}\end{array}$ \\
\hline \multicolumn{4}{|l|}{ National institutional order } \\
\hline Membership to business groups & $0.51^{* * *}(0.19)$ & $0.11(0.27)$ & $0.03(0.24)$ \\
\hline \multicolumn{4}{|l|}{ Transnational and local carriers } \\
\hline Ownership ties with foreign capital & $0.02(0.18)$ & $0.18(0.21)$ & $0.46^{* *}(0.23)$ \\
\hline Membership to Kalder network & $0.54^{* * *}(0.15)$ & - & - \\
\hline Membership to LIT network & - & - & $0.82^{* * *}(0.25)$ \\
\hline $\begin{array}{l}\text { Prior experience and knowledge } \\
\text { complementarity } \\
\text { Prior TQM adoption }\end{array}$ & - & $1.31^{* *}(0.58)$ & $1.50^{* * *}(0.42)$ \\
\hline $\begin{array}{l}\text { Material capability and technologice } \\
\text { sophistication } \\
\text { Organizational size }{ }^{\Omega} \\
\text { Technological sophistication } \\
\text { Constant }\end{array}$ & $\begin{array}{c}0.14^{* *}(0.07) \\
0.07(0.14) \\
-1.09^{* * *}(0.42) \\
\end{array}$ & $\begin{array}{c}0.10(0.10) \\
0.39^{* *}(0.19) \\
-2.50^{* * *}(0.64)\end{array}$ & $\begin{array}{c}0.03(0.83) \\
0.03(0.15) \\
-1.89^{* * *}(0.54)\end{array}$ \\
\hline $\begin{array}{l}\text { Wald } X^{2} ; \text { d.f. } \\
\rho \text { coefficients }(\mathrm{n}, \mathrm{n}) \\
X^{2} \operatorname{test}\left(\rho_{1,2}=\rho_{1,3}=\rho_{2,3}=0\right) ; \text { d.f. }\end{array}$ & $\rho_{1,2}=-0.5$ & $\begin{array}{l}167.13^{* * *} ; 16 \\
\rho_{1,3}=-0.66^{* *} ; \\
44.69^{* * *} ; 3\end{array}$ & $=0.71^{* * *}$ \\
\hline
\end{tabular}

Notes: ${ }^{*}$ indicates significance at $\mathrm{p}<0.10 ;{ }^{* *}$ indicates significance at $\mathrm{p}<0.05 ;{ }^{* * *}$ indicates significance at $p<0.01$. $\rho$ coefficients indicate correlations between the errors of each equation. Figures reported for estimators are standardized Beta coefficients with standard errors reported in parantheses. $\Omega$ indicates natural logarithm transformations are applied to induce normality.

the likelihood of TQM and LP adoption. While this indicates that prior experience, knowledge complementarity and ties developed with local carrier networks may be strong determinants of the adoption of MIs in Turkey, other factors do not consistently predict the likelihood of adoption for each innovation. For instance, membership to local business group networks, which theoretically represents the effects of national institutional configuration, has predicted the adoption of TQM, but not $6 \sigma$ or LP. Likewise, ties developed with transnational carriers have predicted the adoption of LP, but not $6 \sigma$ or TQM. Moreover, the adoption of $6 \sigma$ has been linked with the degree of technological sophistication, whereas TQM and LP has not. Thus, the model estimations suggest that the relative importance of each factor in predicting the likelihood of adoption may drastically vary for particular MIs.

In order to empirically verify the relationship expressed in H6, I have employed a nonparametric test, analogous to the analysis of variance, namely the Jonckheere-Terpstra test. Since the degree of quality entrenchment is a summation score, ranging from 0 to 4 with only integer values, it is better to treat it as an interval scale with an escalating 
order. When there is a natural a priori ordering of the $\mathrm{k}$ populations, Jonckheere-Terpstra test is more powerful over Kruskal-Wallis $\mathrm{H}$ test. While the result of the test statistic is highly significant ( $\mathrm{std}$. J-T statistic $=12.99 ; \mathrm{p}=0.00$ ), indicating strong variation between the entrenchment scores of none, single, double and triple MI users, further cross-tabulation sheds more light into how such variation happened. According to the cross-tabulation of the quality entrenchment scores and the degree of inhabitation/cohabitation, it can be argued that H6 is partly supported.

The patterns discerned from the cross-tabulation of MI inhabitation versus entrenchment scores suggest that Turkish firms, which obtained relatively low scores on quality entrenchment - up to moderate - accounted for more than $80 \%$ of single innovation users, $71.6 \%$ of double innovation users and $44.8 \%$ of triple innovation users. While stronger levels of quality entrenchment is associated with cohabitation of multiple innovations, indicating a more accumulative process for learning, a significant portion of Turkish companies seems to choose ritual, or ceremonial ways of implementation, mostly decoupled from formal processes/roles. Thus, the possibility of superstitious learning is not ruled out for a significant portion of Turkish firms. Conversely, there seems to be other cases - however few - where quality improvement seems to be well entrenched in both first-order and second-order learning routines, leading to the integration of complementary MIs.

\section{Conclusions and discussions}

The current study aims to make a contribution to the extant literature on the adoption of MIs by developing and validating a comprehensive framework, which incorporates supposedly incommensurable theoretical perspectives. The framework is built on the logic of contactual relations between an external and local party, by which the latter acquires and assimilates a peculiar MI. It specifies a set of theoretical factors that determine and regulate such contacts, devoting special attention to the conditions that can be observed in less advanced country settings. I argue in this paper that by locating dominant economic actors, transnational and local carriers within a national setting and specifying the mechanisms through which these social actors connect between themselves and with local organizational actors, it becomes possible to better predict the ways by which MIs are channeled into the local setting. Moreover, I further assert that the local organizational actors are no passive consumers, and thus, their capacity to acquire and assimilate these MIs should also be taken into account. Specifically, it has been found out that a prior adoption decision made by a firm for a particular MI, namely TQM, has significant potency to determine consecutive adoption decisions made for conceptually related MIs (i.e. $6 \sigma$ and LP). In this manner, the framework developed in this study represents a significant contribution and has potency to be applied, at least, to other less advanced settings, whose peculiarities are understated within the existing theories of adoption.

While the empirical evidence has supported the new framework as a whole, the results also suggest that the relative importance of the components of the framework can significantly vary in explaining the adoption patterns of different MIs. Variations among 
the explanatory factors can be attributed to the differences between the life-cycles of TQM, $6 \sigma$ and LP as well as to the relative divergence of their conceptual framing. By elaborating each adoption pattern seperately it becomes easier to decipher how the components of the integrative model work in cohort to emphasize different factors for different MIs.

For instance, nationally institutionalized ownership networks - be they business group affiliations, or local quality associations led by the former - seem to account for almost all of the local adoption dynamics of TQM in Turkey. Large-sized affiliates of the prominent business groups and members of Kalder have adopted TQM regardless of their technological sophistication level. Considering that no significant abandonment pattern has ensued up till now, it is possible to interpret TQM as an entrenched MI in Turkey. Hence, it is understandable that the local adoption pattern of TQM is predominantly explained by social factors rather than material ones based on the logic of legitimacy gains.

The adoption pattern of $6 \sigma$, on the other hand, exhibits a somewhat different portrayal. Since $6 \sigma$ incorporates a rather technical conceptual core based on complex data driven methodologies, strictly formulated project arrangements, and explicitly defined role prescriptions (Dahlgaard, Dahgaard-Park 2006), it requires more absorptive capacity on the part of the recepient party to acquire and assimilate such technical content. Therefore, both technological sophistication level and prior experience with TQM significantly predicted the likelihood of $6 \sigma$ adoption in Turkey rather than the remaining factors.

The adoption of LP does not rely on material sources of absoptive capacity and depends relatively less on prior experience with TQM, but rests more on the ties developed with transnational ownership networks and professional carriers. This is also understandable, because LP is more comprehensive, and less technically articulated compared to $6 \sigma$, thereby requiring relatively less absorptive capacity to acquire and assimilate. In this sense, TQM and LP are conceptually more similar. The difference between the determinants of the adoption patterns of TQM and LP stems from their life-cycles and relative transformation of the Turkish context during that time lag. Liberalization efforts and relative intensification of market framework in Turkey during the second half of 2000s have amplified the influence of transnational and local carriers on the adoption of MIs. While Kalder had predominantly exploited the ties developed with dominant business groups, thus built mostly on the structural components of the NBS configuration, LIT did not enjoy such a structural advantage, but instead, had exploited a transnational one, built with the Lean Enterprise Institutes all over the globe.

While separate elaborations of each adoption pattern further elucidates how components of the model work in concert, the reluctance of Turkish firms to abandon MIs even when they adopt a newer and conceptually related MI requires more theoretical scrutiny. As it has been discussed earlier, there is a tension within the literature concerning if organizations superstitiously learn, or substantively assimilate MIs (cf. Abrahamson, Fairchild 1999; Zeitz et al. 1999; Perkmann, Spicer 2008). The consequences of following each path are quite apart; the former leading to fashionable use and abandonment, whereby 
the latter resulting in entrenchment, saturation and institutionalization. Evidence drawn from the Turkish setting suggests that there are followers for both paths. While some firms accumulate and creatively recombine MIs with each other, there are significant number of others, which 'appear to' cohabit multiple MIs, perhaps just to retain their "innovative" outlook under legitimacy concerns.

\section{Limitations and further research implications}

The results reported in the study are subject to limitations of data. Since the data are collected with a cross sectional design and over the phone, it has become impossible to design a comprehensive panel data analytic model, which integrates various firm level explanatory and/or control factors (such as the proportion and/or number of skilled workforce, consultancy use, non-equity based inter-organizational ties etc.) as well as the effect of time. Even though the estimations are carried out with the best available techniques, because of the data limitations, considerable risk exists that the reported estimates may represent simple correlates rather than strict causal relationships.

Apart from such limitations, further research is strongly encouraged to test consecutive or simultaneous interaction between different MIs either at the conceptual or practical level. The results obtained from the study have confirmed the fact that more has to be done to expand our current frameworks to explain how MIs are adopted and diffused in less advanced contexts. Further testing of the findings reported in this study may help to transform our existing theoretical standpoints regarding cohabitation of multiple MIsin-use and the mechanisms about how organizations are able to handle it.

\section{Acknowledgement}

This study has been funded by the The Scientific and Technological Research Council of Turkey (TUBITAK), Project no. 108K577. An earlier version of this study has been presented at the $26^{\text {th }}$ EGOS Colloquium, Lisbon, Portugal. The author greatly acknowledges the contributions made by Saime Suna Kayam and anonymous reviewers for further development of the paper.

\section{References}

Abrahamson, E. 1996. Management fashions, Academy of Management Review 21(1): 254-265.

Abrahamson, E.; Fairchild, G. 1999. Management fashion: lifecycles, triggers, and collective learning processes, Administrative Science Quarterly 44: 708-740. http://dx.doi.org/10.2307/2667053

Ansari, S. M.; Fiss, P. C.; Zajac, E. J. 2010. Made to fit: how practices vary as they diffuse, Academy of Management Review 35: 67-92. http://dx.doi.org/10.5465/AMR.2010.45577876

Antony, J. 2007. Is six sigma a management fad or fact?, Assembly Automation 27: 17-19. http://dx.doi.org/10.1108/01445150710724658

Arias, M. E.; Guillén, M. F. 1998. The transfer of organizational techniques across borders: combining neo-institutional and comparative perspectives, in J. L. Alvarez (Ed.). The diffusion and consumption of business knowledge. London: Macmillan, 110-137. 
Birkinshaw, J.; Hamel, G.; Mol, M. J. 2008. Management innovation, Academy of Management Review 33: 825-845. http://dx.doi.org/10.5465/AMR.2008.34421969

Bloom, N.; Van Reenen, J. 2010. Why do management practices differ across firms and countries?, Journal of Economic Perspectives 24: 203-224. http://dx.doi.org/10.1257/jep.24.1.203

Buğra, A. 1994. State and business in modern Turkey. New York: New York University Press.

Cappellari, L.; Jenkins, S. J. 2003. Multivariate probit regression using simulated maximum likelihood, The Stata Journal 3: 278-294.

Carson, P. P.; Lanier, P. A.; Carson, K. D.; Guidry, B. N. 2000. Clearing a path through the management fashion jungle: some preliminary trailblazing, Academy of Management Journal 43: 1143-1158. http://dx.doi.org/10.2307/1556342

Clark, T.; Greatbatch, D. 2002. Whose idea is it anyway? Collaborative relationships in the creation and fashioning of management ideas: gurus, editors and managers, in M. Kipping, L. Engwall (Eds.). Management consulting: emergence and dynamics of a knowledge industry. New York: Oxford University Press, $129-145$.

Cohen, M. W.; Levinthal, D. A. 1990. Absorptive capacity: a new perspective on learning and innovation, Administrative Science Quarterly 35: 128-152. http://dx.doi.org/10.2307/2393553

Corbett, C. J.; Kirsch, D. A. 2001. International diffusion of ISO 14000 certification, Production and Operations Management 10: 327-342. http://dx.doi.org/10.1111/j.1937-5956.2001.tb00378.x

Crossan, M.; Lane, H.; White, R. 1999. An organizational learning framework: from intuition to institution, Academy of Management Review 24: 522-537.

Çolpan, A.; Hikino, T. 2008. Türkiye'nin büyük şirketler kesiminde işletme gruplarının iktisadi rolü ve çeşitlendirme stratejileri, Yönetim Araştırmaları Dergisi 8: 23-58.

Dahlgaard, J. J.; Dahlgaard-Park, S. M. 2006. Lean production, six sigma quality, TQM and company culture, The TQM Magazine 18: 263-281. http://dx.doi.org/10.1108/09544780610659998

Damanpour, F. 1992. Organizational size and innovation, Organizational Studies 13: 375-402. http://dx.doi.org/10.1177/017084069201300304

Da Silveira, G. 2001. Innovation diffusion: a research agenda for developing countries, Technovation 21: 761-773. http://dx.doi.org/10.1016/S0166-4972(01)00007-4

David, R. J.; Strang, D. 2006. When fashion is fleeting: transitory collective beliefs and dynamics of TQM consulting, Academy of Management Journal 49: 215-233.

http://dx.doi.org/10.5465/AMJ.2006.20786058

Djelic, M.-L.; Quack, S. 2003. Theoretical building blocks for a research agenda linking globalization and institutions, in M.-L. Djelic, S. Quack (Eds.). Globalization and institutions. redefining the rules of the economic game. Cheltentham, UK: Edward Elgar, 15-36.

Erçek, M. 2008. Spread of management fashions in peripheral business systems: the role of Turkish business groups in consuming, adopting and diffusing six sigma, in The 24th EGOS Colloquium, 10-12 July 2008, Amsterdam: VU University.

Erçek, M.; Günçavd1, Ö. 2010. Evolution of national and international resource constraints and business groups: the historical case of a Turkish family holding, 1950-1999, Business and Economic History On-line, vol. 8 [online], [cited 15 November 2011]. Available from İnternet:

http://www.thebhc.org/publications/BEHonline/2010/ercekandguncavdi.pdf

Erçek, M.; İşeri-Say, A. 2008. Discursive ambiguity, professional networks, and peripheral contexts: the translation of total quality management in Turkey, 1991-2002, International Studies of Management and Organization 38(4): 78-99. http://dx.doi.org/10.2753/IMO0020-8825380404

Gavetti, G.; Levinthal, D. 2000. Looking forward and looking backward: cognitive and experiential search, Administrative Science Quarterly 45: 113-137. http://dx.doi.org/10.2307/2666981 
Gökşen, N. S.; Üsdiken, B. 2001. Uniformity and diversity in Turkish business groups: effects of scale and time of founding, British Journal of Management 12(4): 325-340.

http://dx.doi.org/10.1111/1467-8551.00213

Grint, K. 1997. TQM, BPR, JIT, BSCs \& TLAs: managerial waves or drownings?, Management Decision 35: 731-738. http://dx.doi.org/10.1108/00251749710192048

Guillén, M. F. 1994. Models of management: work, authority, and organization in a comparative perspective. Chicago: University of Chicago Press.

Haar, J. M.; Spell, C. S. 2008. Predicting total quality management adoption in New Zealand: the moderating effect of organisational size, Journal of Enterprise Information Management 21: 162-178. http://dx.doi.org/10.1108/17410390810851408

Heusinkveld, S.; Benders, J. 2012. On sedimentation in management fashion: an institutional perspective, Journal of Organizational Change Management 25(1): 121-142.

http://dx.doi.org/10.1108/09534811211199628

Heusinkveld, S.; Benders, J.; Hillebrand, B. 2013. Stretching concepts: the role of competing pressures and decoupling in the evolution of organization concepts, Organization Studies 34: 7-32.

http://dx.doi.org/10.1177/0170840612464748

ISPAT (The Republic of Turkey Prime Ministry Investment Support and Promotion Agency). 2011. FDI in Turkey [online], [cited 10 November 2011]. Available from İnternet:

http://www.invest.gov.tr/EN-US/investmentguide/investorsguide/Pages/FDIin Turkey.aspx

İseri-Say, A.; Toker, A.; Kantur, D. 2008. Do popular management techniques improve performance? Evidence from large businesses in Turkey, Journal of Management Development 27(7): 660-677. http://dx.doi.org/10.1108/02621710810883580

Juran, J. M.; Godfrey; A. B. 1998. Juran's quality handbook. 5th ed. New York: Mc Graw Hill.

Kennedy, M. T.; Fiss, P. C. 2009. Institutionalization, framing, and the logic of TQM adoption and implementation decisions among U.S. hospitals, Academy of Management Journal 52: 897-918.

http://dx.doi.org/10.5465/AMJ.2009.44633062

Kepenek, Y.; Yentürk, N. 2001. Türkiye ekonomisi. 12th ed. İstanbul: Remzi Kitabevi.

Keyman, E. F.; Öniş, Z. 2007. Turkish politics in a changing world. Global dynamics and domestic transformations. İstanbul: İstanbul Bilgi University Press.

Khanna, T.; Palepu, K. G. 1999. Policy shocks, market intermediaries, and corporate strategy: the evolution of business groups in Chile and India, Journal of Economics and Management Strategy 8(2): 271-310. http://dx.doi.org/10.1162/105864099567668

Kimberly, J. R.; Evanisko, M. J. 1981. Organizational innovation: the influence of individual, organizational, and contextual factors on hospital adoption of technological and administrative innovations, Academy of Management Journal 24: 689-713. http://dx.doi.org/10.2307/256170

Kipping, M.; Engwall, L.; Üsdiken, B. 2008. Preface: the transfer of management knowledge to peripheral countries, International Studies of Management and Organization 38(4): 3-13.

http://dx.doi.org/10.2753/IMO0020-8825380400

Lane, P. J.; Lubatkin, M. 1998. Relative absorptive capacity and interorganizatinoal learning, Strategic Management Journal 19: 461-477.

http://dx.doi.org/10.1002/(SICI)1097-0266(199805)19:5<461::AID-SMJ953>3.0.CO;2-L

Lichtenthaler, U. 2009. Absorptive capacity, environmental turbulance and the complemantarity of organizational learning processes, Academy of Management Journal 52: 822-846.

http://dx.doi.org/10.5465/AMJ.2009.43670902

Modell, S. 2009. Bundling management control innovations: a field study of organisational experimenting with total quality management and the balanced scorecard, Accounting, Auditing \& Accountability Journal 22: 59-90. http://dx.doi.org/10.1108/09513570910923015 
Öniş, Z.; Şenses, F. 2007. Global dynamics, domestic coalitions and a reactive state: major policy shifts in post-war Turkish economic development, METU Studies in Development 34: 251-286.

Özen, Ş. 2002. Bağlam, aktör, söylem ve kurumsal değişim: Türkiye'de toplam kalite yönetiminin yayılım süreci, Yönetim Araştırmaları Dergisi 2(1): 47-90.

Özen, Ş.; Berkman, Ü. 2007. Cross-national reconstruction of managerial practices: TQM in Turkey, Organization Studies 28: 825-851. http://dx.doi.org/10.1177/0170840607079863

Perkins, R.; Neumayer, E. 2010. Geographic variations in the early diffusion of corporate voluntary standards: comparing ISO 14001 and the Global Compact, Environment and Planning A 42: 347-365. http://dx.doi.org/10.1068/a4249

Perkmann, M.; Spicer, A. 2008. How are management fashions institutionalized? The role of institutional work, Human Relations 61: 811-844. http://dx.doi.org/10.1177/0018726708092406

Pepper, M. P. J.; Spedding, T. A. 2009. The evolution of lean six sigma, International Journal of Quality and Reliability Management 27: 138-155. http://dx.doi.org/10.1108/02656711011014276

Sahlin-Andersson, K.; Engwall, L. 2002. Carriers, flows, and sources of management knowledge, in K. Sahlin-Andersson, L. Engwall (Eds.). The expansion of management knowledge. Stanford, CA: Stanford University Press, 3-32.

Sanders, W. M. G.; Tuschke, A. 2007. The adoption of institutionally contested organizational practices: the emergence of stock option pay in Germany, Academy of Management Journal 50: 33-56. http://dx.doi.org/10.5465/AMJ.2007.24160889

Sayım, K. Z. 2011. Policy transfer from advanced to less advanced institutional environments: labor market orientations of US MNEs in Turkey, Human Relations 64: 573-597.

Senapati, R. N. 2004. Six sigma: myths and realities, International Journal of Quality and Reliability Management 21: 683-690.

Shah, R.; Ward, P. T. 2007. Defining and developing measures of lean production, Journal of Operations Management 25: 785-805.

Smith, C.; Meiksins, P. 1995. System, society and dominance effects in cross-national organisational analysis, Work Employment Society 9: 241-267.

Spell, C. S. 2001. Management fashions: where do they come from? Are they old wine in new bottles, Journal of Management Inquiry 10: 358-372. http://dx.doi.org/10.1177/1056492601104009

Sturdy, A. 2004. The adoption of management ideas and practices: theoretical perspectives and possibilities, Management Learning 35: 155-180. http://dx.doi.org/10.1177/1350507604043023

Todorova, G.; Durisin, B. 2007. Absorptive capacity: valuing a reconceptualization, Academy of Management Review 32: 774-786. http://dx.doi.org/10.5465/AMR.2007.25275513

Tolbert, P.; Zucker, L. G. 1996. The institutionalization of institutional theory, in S. R. Clegg, C. Hardy, W. R. Nord (Eds.). Handbook of organization studies. London: Sage, 175-190.

Westphal, J. D.; Gulati, R.; Shortell, S. M. 1997. Customization or conformity? An institutional and network perspective on the content and consequences of TQM adoption, Administrative Science Quarterly 42: 366-394. http://dx.doi.org/10.2307/2393924

Whitley, R. 1999. Divergent capitalisms: the social structuring and change of business systems. Oxford: Oxford University Press. http://dx.doi.org/10.1177/017084069001100105

Whitley, R. 2000. East Asian enterprise structures and the comparative analysis of forms of business organization, Organization Studies 11: 47-74.

Whitley, R.; Kristensen, P. H. (Eds.). 1996. The changing European firm: limits to convergence. London: Routledge.

Womack, J. P.; Jones, D. T. 1996. Lean thinking: banish waste and create wealth in your corporation. New York: Simon Schuster. 
Wright, C.; Kwon, S.-H. 2006. Business crises and management fashion: Korean companies, restructuring and consulting advise, Asian Pacific Business Review 12: 355-373.

http://dx.doi.org/10.1080/13602380600597034

Yiu, D. W.; Lu, Y.; Bruton, G. D; Hoskisson, R. E. 2007. Business groups: an integrated model to focus future research, Journal of Management Studies 44: 1551-1579.

http://dx.doi.org/10.1111/j.1467-6486.2007.00735.x

Zahra, S. A.; George, G. 2002. Absorptive capacity: a review, reconceptualization, and extension, Academy of Management Review 27: 185-203.

Zeitz, G.; Mittal, V.; McAulay, B. 1999. Distinguishing adoption and entrenchment of management practices: a framework for analysis, Organization Studies 20: 741-776.

http://dx.doi.org/10.1177/0170840699205003

Mehmet ERÇEK is an Associate Professor of Management Engineering in the Faculty of Management at Istanbul Technical University (Istanbul, Turkey). He holds a $\mathrm{PhD}$ degree from Boğaziçi University (Istanbul, Turkey). His research interests are in the areas of diffusion of management knowledge, business and management history and applied organization theory. His research has appeared in journals such as International Journal of Human Resources Management, International Studies of Management and Organization, and Systemic Practice and Action Research as well as various other Turkish outlets. 